\title{
Rats and Mice (Destruction) Act, 1919.-Administrative Difficulties.
}

\author{
By Geo. L. Moore, County Organising Officer under Rats and Mice \\ (Destruction) Act, 1919, to Kent County Council.
}

$\mathrm{T}^{\mathrm{H}}$

$\mathrm{HE}$ onus of destruction under the Rats and Mice (Destruction)

Act, 1919, is rightly placed upon the occupier of infested premises (as also the duty of taking all necessary and reasonably practicable steps to prevent premises becoming infested), but in many instances the occupier of infested premises has neither the knowledge nor the means of effecting a clearance, though quite willing to have destructive measures taken by skilled exterminators at his expense. A Local Authority, in addition to their own obligations as occupiers, while empowered under the Act to employ men for the carrying out of its direct cluties (i.e., after a Notice has been served under Section 5 (1), would not be justified in the opinion of the Legal Advisers to the Ministries of Agriculture and Health, in employing men for the sole purpose of contract work of Rat destruction, even though the cost of such destructive work be recovered. The only effective method for ensuring uniformity and continuity of action being the employment of a permanent staff of skilled Rat Exterminators under the control of the Local Authority, and while it is not to be assumed that the Local Government Auditors would unduly criticise any unrecovered expenses in connection with such a Staff, such a scheme should not be open to criticism. On the other hand, the employment of a competent and efficient destructive Staff, whose services would be available to occupiers at a reasonable charge, should not only be permissible under the Act, but a part of its administrative machinery.

The payment of rewards by Local Authorities for rats killed is, under proper supervision in rural areas, a means of keeping their numbers in check. A reward of $2 \mathrm{~d}$. per tail has proved, in Kent, a sufficient incentive to the desired end.

Properly organised Rat Clubs were formed, whose funds were augmented by Local Authorities paying 2d. per tail for each rat killed, subject to a proper scheme of supervision. Considerable success had been achieved, the number of Rat Clubs within the County had increased from thirteen, in August, 1919, to seventy, in the following April. Thirteen Clubs for the year ending 31st March, 1920, had accounted for 35,664 rats, besides a large number of mice, sparrows, queen wasps, and other destructive agricultural pests. 
The decision of the Ministry of Health as to the legality of the payment of rewards by Local Authorities out of public funds for rats killed will necessarily have a retarding effect in the formation of further Clubs, and a tendency to lessen the efforts of existing ones. A number of rural areas in Kent have been kept comparatively free from rats entirely by the activities of Rat Clubs, and in no case has the payment of a reward of so modest a sum been found conducive to the encouragement of the breeding of rats by unscrupulous persons.

When a County Council has delegated its powers and duties under the Act to the minor Local Authorities within the Administrative County, there is a difficulty in securing uniformity of action. Minor Local Authorities cannot be expected to appoint whole-time Rat Officers, and consequently the administration of the Rats Act is added to the duties of an Official who already has his time more or less occupied with other duties, and for this additional work there is in some instances no extra remuneration. As a result, the Act is not always administered efficiently.

The insanitary and unsatisfactory system of refuse disposal obtaining in many districts, due to the absence of refuse destructors, is a frequent cause of the prevalence of rats. One would have thought it impossible, at the present time, for such primitive methods to be tolerated. While this is a matter primarily for the Sanitary Authorities to deal with, it has a direct bearing upon the rat problem. Where Local Authorities do not feel justified in providing the whole cost of a destructor, it should be possible for adjoining Local Authorities to share the expense of providing a destructor jointly. Pending the provision of a destructor, garbage and regetable matter (which are the attraction for rats) might be separated from the general refuse and dealt with by means of an incinerator at a comparatively small cost. In several instances Local Authorities are themselves the greatest harbourers of rats in the district.

Consistency of action throughout the country is, in my opinion, necessary for success. While the propaganda work which has been clone has been the means of bringing the rat menace to more general notice, and has aroused a certain amount of interest, the measures recommended have been too general to be of real service. Poisoning through safe media has been advocated, and rightly so, though sufficient emphasis has not been made of the fact that no amount of poisoning will serve to clear a district unless ratproofing measures are taken immediately following a clearance, which will prove only temporary unless preventive measures are taken for the protection of premises and of the food supply. 


\section{Decision of the Council on Resolution passed at the Birmingham Congress,} 1920.

SECTION A.-SANITARY SCIFXCE AND PREVENTIVE MIEDICINE.

(1) That it is desirable in the public interest and on public health grounds that the sale of any liquid as a "Disinfectant" should be controlled by legislation.

(2) That such legislation should demand:-That any liquid sold as "Disinfectant" should have a carbolic acid coefficient (as tested by an approved method) of at least one. That a penalty should be imposed (a) for any false or misleading statements as to the germicidal value of a disinfectant, and (b) for any misleading instructions with reference to the effective use of a disinfectant.

(3) That copies of these resolutions be forwarded to each of the Borough Councils of Great Britain inviting them to pass similar resolutions; and that the Ministry of Health be informed of the results.

A copy of this resolution was circulated to Metropolitan and County Boroughs, and 55 of these Authorities approved or passed similar resolutions. The resolution was then forwarded on to the Ministry of Health.

\section{OBITUARY.}

Sir Charles Alex. Camerox, C.B., M.D., Ph.D., F.R.C.S.I.

A notable and striking figure in the Public Health Service passed from the stage on the 27th February last in the person of Sir Charles Alex. Cameron, C.B., M.D., Ph.I)., F.R.C.S.I., Medical Officer of Health for the City of Dublin. He had been in failing health for some time, but retained office to the last with faculties unimpaired, and had attended to his duties at the Council House until within a few weeks of his death.

Charles Alex. Cameron was born in Dublin on July 16th, 1830, and was, therefore, in his 91 st year at the time of his death. He came of good stock, his father, Captain Ewan Cameron (an officer in the British Army) being a great-grandson of the celebrated John Cameron of Lochiel. He received his early education in Dublin, but, after his father's death, which occurred when he was 14 years of age, he went to Germany, where he completed his education and obtained his medical training, taking degrees there in medicine

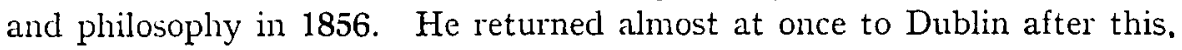

